\title{
Safety of Oral P2Y12 Inhibitors in Interventional Neuroradiology: Current Status and Perspectives
}

\author{
(D)L.M. Camargo, (DP.C.T.M. Lima, (D) K. Janot, and (DI.L. Maldonado
}

\begin{abstract}
SUMMARY: In the field of interventional neuroradiology, antiplatelet agents are commonly used to prepare patients before the implantation of permanent endovascular materials. Among the available drugs, clopidogrel is the most frequently used one, but resistance phenomena are considered to be relatively common. Prasugrel and ticagrelor were recently added to the pharmacologic arsenal, but the safety of these agents in patients undergoing neurointerventional procedures is still a subject of discussion. The cumulative experience with both drugs is less extensive than that with clopidogrel, and the experience with patients in the neurology field is less extensive than in the cardiology domain. In the present article, we provide a narrative review of studies that investigated safety issues of oral P2Y12 inhibitors in interventional neuroradiology and discuss potential routes for future research.
\end{abstract}

ABBREVIATION: CYP $=$ cytochrome P450

A ntiplatelet agents are commonly used to prepare patients before the implantation of permanent endovascular materials. In the field of interventional neuroradiology, oral P2Y12 inhibitors are used in combination with aspirin for dual-antiplatelet therapy. Clopidogrel is the most frequently used P2Y12 inhibitor for this kind of preparation. As a prodrug, it is transformed into its active form by the liver and acts through an irreversible blockade of the adenosine diphosphate receptor in the plasmatic membrane of platelets. ${ }^{1-7}$ There is evidence of a prophylactic effect in subjects with a history of transient ischemic attack and ischemic stroke. ${ }^{8,9}$ Clopidogrel use also reduces the occurrence of thromboembolic adverse events during angioplasty and stent placement. ${ }^{1,4,10-12}$ In some individuals, however, the use of clopidogrel does not have the desired effect. Nonresponsive patients are usually classified as drug-resistant..$^{2-5,10,13-17}$ Because interventional neuroradiology procedures not infrequently include the implantation of definitive endovascular prostheses such as stents or flow diverters, resistance

Received March 15, 2021; accepted after revision July 22.

From the Faculdade de Medicina (L.M.C.), Universidade Salvador, Salvador, Brazil; Serviço de Clínica Médica (P.C.T.M.L.), Hospital Santo Antônio, Associação Obras Sociais Irmã Dulce, Salvador, Brazil; Service de Neuroradiologie (K.J.), Centre Hospitalier Régional Universitaire de Tours, Tours, France; and U1253, iBrain (I.L.M.), Université de Tours, Institut National de la Santé et de la Recherche Médicale, Tours, France.

Please address correspondence to Igor Lima Maldonado, MD, PhD, UMR 1253, iBrain, Université de Tours, Inserm, Tours, France, 10 Boulevard Tonnellé, 37032 Tours, France; e-mail: limamaldonado@univ-tours.fr

- Indicates open access to non-subscribers at www.ajnr.org

Indicates article with online supplemental data.

http://dx.doi.org/10.3174/ajnr.A7303 may lead to intrastent thrombosis with vessel occlusion or stenosis. ${ }^{3,5,11,16-21}$ This increased risk seems to not only concern the perioperative period but extends postoperatively as well. ${ }^{2,3,14}$

Since the advice of the FDA on clopidogrel hyporesponsiveness in $2010,{ }^{22,23}$ alternative drugs have been studied at greater lengths. In the context of both preoperative preparation and postoperative antiaggregation, 2 other oral agents, prasugrel ${ }^{24-37}$ and ticagrelor, ${ }^{2538-46}$ have been intensively discussed (Online Supplemental Data). Prasugrel is a third-generation thienopyridine, a group of drugs that irreversibly inhibits the P2Y12 receptor and, consequently, adenosine diphosphate-dependent activation and platelet aggregation. ${ }^{7,47}$ Ticagrelor is a cyclopentyltriazolopyrimidine, which is directly active after administration, thereby differentiating it from thienopyridines. ${ }^{48}$ The cumulative experience with these 2 antiplatelet agents in interventional neuroradiology is, however, less extensive than with clopidogrel. In the present article, we provide a narrative review of studies that investigated safety issues with oral P2Y12 inhibitors (clopidogrel, prasugrel, and ticagrelor) in interventional neuroradiology and discuss potential routes for future research.

\section{Clopidogrel Resistance in Interventional Neuroradiology}

Resistance to clopidogrel increases the risk of endovascular procedures, a phenomenon that was first described in the cardiology literature. ${ }^{2,3,11,14,16,19,28,29,49-51}$ The criterion standard method to identify resistant patients is laboratory light transmission aggregometry. ${ }^{5,7}$ To detect poor responders promptly, point-of-care tests have been developed and widely used both for their convenience and speed. Specifically, they assess the action of the drug at 
bedside and make possible adjustments to the care of high-risk patients. One of the most widely distributed is the VerifyNow P2Y12 assay (Accumetrics), a portable device that enables measurement in a blood sample without preparation or centrifugation. ${ }^{5,7}$ It presents the results initially in $\mathrm{P} 2 \mathrm{Y} 12$ reactive units and allows the calculation of the percentage of inhibition.

The values (either the number of units or the percentage of inhibition) can be used to classify the patient as a responder or nonresponder by applying a threshold defined by the operator. Many authors consider $>40 \%$ to be an adequate inhibition rate. ${ }^{2,5,52,53}$ However, because an intermediate response is observed above $20 \%$, others propose to consider only patients with $<20 \%$ as resistant. ${ }^{14}$ The manufacturer presents 208 P2Y12 reactive units as the target under which specific evidence of a pharmacodynamic effect has been observed, being also associated with the reduction of thrombosis and increase of bleeding rates. Neurointerventional studies, however, have used different cutoffs in varied contexts, varying from 208 to $295 .{ }^{12,20,27-29,31,40,54}$ A value of $<60$ was reported to be associated with a higher risk of hemorrhagic complications. ${ }^{28,29}$ In a study of 279 patients under dual antiplatelet therapy, a value of 175 was observed to discriminate patients with hemorrhagic complications from those without. ${ }^{21}$ In another study in 47 patients, focused on the bleeding risk of the 7 patients defined as hyper-responders ( $\geq 72 \%$ of platelet inhibition), 3 patients $(42.8 \%)$ had a major bleeding complication. ${ }^{55}$

An important clinical issue is the degree of platelet inhibition obtained after a single loading dose-ie, a higher dose of the drug that can be administered at the beginning of the treatment before dropping to a lower maintenance dose. By means of $40 \%$ as a threshold, up to $64 \%$ of patients exhibited a low response after $300 \mathrm{mg}$ of clopidogrel. ${ }^{2,5,11,52,53}$ The absence of a precise definition of low response as well as the multiplicity of diagnostic methods have contributed to the variation in the figures reported, especially in the initial series. Some studies have suggested that the drug resistance is related to genetic polymorphisms, but individual factors, such as diabetes mellitus, age older than 65 years, hypercholesterolemia, weight, adherence to treatment, and concomitant drugs also play a role. . $3,5,6,15,56^{-}$

A typical example of genetic polymorphism is the alteration of the enzyme cytochrome (CYP)2C19, which is involved in the metabolism of clopidogrel. Altered alleles lead to high platelet reactivity despite clopidogrel administration, but great variability is noted within each genotype group. ${ }^{57}$ Genetic alterations involving the P2Y12 receptor also occur. ${ }^{1,5}$ Nevertheless, because resistant individuals have less exposure to the active metabolite, it is possible that the resistance is more associated with the concentration of the active metabolite than with insufficient sensitivity of the P2Y12 receptor. ${ }^{58}$ The effectiveness of clopidogrel depends on factors that influence both the metabolite concentration and final effect. The result is a variable response. ${ }^{57}$

Specific genetic testing can identify patients with constitutional alterations in clopidogrel metabolism. ${ }^{14}$ In clinical practice, these tests are generally used after the patient shows a clinical or laboratory manifestation of resistance. A particular difficulty is the time these examinations usually demand ( $\geq 5$ days). It is also known that a subject can present with the normal allele and be resistant for other reasons. Conversely, a given patient who has the altered allele may have low platelet activity due to mechanisms not yet fully elucidated, limiting the predictive value of genetic testing. ${ }^{57}$ Considering the cost and impracticality of genetic testing and the great variability of the causal factors, it has been preferable in daily practice to perform tests that evaluate the final drug effect, ie, platelet aggregation. ${ }^{7}$

Interest in the epigenetics of clopidogrel resistance has also increased in the past years. Most studies focus on microRNA and DNA methylation. MicroRNA molecules can bind to RNA and interfere with transcription. MiR-26, miR-28, and miR-96 are possible regulators of platelet activity through different mechanisms. ${ }^{59,60}$ Considerable discussion exists regarding miR-223 as a potential biomarker because higher miR-223 levels were associated with better platelet inhibition after clopidogrel administration. ${ }^{60,61}$ Hypomethylation of a number of promoters, such as abc1, abc3, and P2RY12 possibly decreases platelet reactivity, but the results have not been homogeneous. ${ }^{60,62}$ Decreased methylation of P2RY12 was associated with clopidogrel resistance in patients with coronary artery disease. ${ }^{60,63}$

The FDA has recommended considering alternative dosing strategies for clopidogrel or using another antiplatelet drug in resistant patients. ${ }^{22,23}$ Although the increase in the loading dose from 300 to $600 \mathrm{mg}$ decreases the percentage of low responses in general, doubling the dose in patients with the genetic mutation did not significantly alter final aggregation rates. ${ }^{3,5,57,64}$ Patients with increased baseline levels of platelet aggregation are also more susceptible to antiplatelet resistance; this issue is seen in those presenting with diabetes mellitus or recent thrombotic events. ${ }^{5,52,56}$ An illustration of this issue is that low-dose aspirin does not have the same antithrombotic effects if there is concomitant arthritis, surgical stress, or diabetes mellitus. ${ }^{65}$ In this specific situation, it is believed that the oxidative stress and elevated C-reactive protein can compensate for and overcome the inhibitory effect on cyclooxygenase 1 .

Thromboembolic complications are multifactorial. Failure of therapy may also be a result of drug interactions. Among the main interactions, the use of proton pump inhibitors, particularly omeprazole, has been described as a factor that decreases the active metabolite of clopidogrel by altering the prodrug metabolism. ${ }^{7,14}$ Ketoconazole is a potent CYP3A inhibitor and has also been reported to reduce the plasma level of the active metabolite of clopidogrel by about $50 \%$ in addition to reducing the antiplatelet effect. ${ }^{66,67}$ The same was observed to a lesser degree with erythromycin and troleandomycin, which are CYP3A4 inhibitors. ${ }^{67}$ Aspirin resistance, though less frequent, also increases the risk of undesirable events in patients on dual-antiplatelet therapy. ${ }^{68}$ On the other hand, rifamycin is acknowledged to be a CYP3A4 inducer, capable of increasing the active metabolite formation and antiplatelet effect of clopidogrel. ${ }^{67,69}$ Similar observations have been made in smokers for reasons possibly related to the CYP1A-inducing effect of polycyclic aromatic hydrocarbons. $^{70-72}$

An inverse relationship between body mass and response to clopidogrel has also been noted. ${ }^{2,6,11,15}$ In 2008 , Lee et $\mathrm{al}^{2}$ reported an association between high body mass and a low response in a population of patients with cerebrovascular disease. In 2014, the results of 182 VerifyNow tests in a consecutive series of 
interventional neuroradiology procedures were analyzed after a 300-mg loading dose. ${ }^{11}$ In subjects weighing $>60 \mathrm{~kg}$, significantly lower percentages of antiaggregation and a higher prevalence of resistance were observed, regardless of the cutoff (20\% or $40 \%)$. This phenomenon may have important implications regarding the way we prepare patients for neuroendovascular treatment. Although the exact mechanism is not yet understood, it is supposedly related to the volume of distribution and pharmacokinetics of the drug, as is the case with other antithrombotic agents (eg, heparin and platelet glycoprotein IIb/IIIa inhibitors). ${ }^{52}$ For clopidogrel, dose adjustment has not been regularly advocated in the past, and traditional preoperative preparation protocols have usually recommended a homogeneous single loading dose of $300 \mathrm{mg}$. ${ }^{2,52}$

Some authors have observed an association between body mass index and resistance to clopidogrel. ${ }^{52,73}$ This association with the index, not just absolute values of body mass, favors implicating metabolic phenomena, not just a pharmacokinetic mechanism, in clopidogrel resistance. Wagner et $\mathrm{al}^{6}$ hypothesized that less exposure to the active metabolite may be a mechanism of low response in overweight patients. It has been suggested that overweight patients may have higher baseline platelet activity compared with normal-weight patients. This difference is maintained under clopidogrel, with overweight subjects presenting suboptimal responses more frequently. ${ }^{7,52}$

It is important to distinguish truly resistant patients and those for whom clopidogrel inefficacy is due to pharmacokinetics. In individuals who are resistant due to pharmacodynamic factors, dose changes would have no significant effect. For the other patients, case-by-case dosage adjustment can be discussed. Consequently, the use of the term "resistance" to describe every therapeutic failure may not be appropriate because it would denote a necessarily persistent situation. In patients undergoing coronary stent angioplasty, increasing the standard dose was reported to improve platelet inhibition without increasing the risk of bleeding. ${ }^{52}$ Nevertheless, these data should be interpreted with caution because patients with cerebrovascular disease belong to a very different population, and hemorrhagic accidents are more frequent in neuroendovascular procedures than in interventional cardiology. Interest in tailoring doses was, however, first and more frequently addressed in cardiology than in neuroradiology. ${ }^{64,74-77}$ A loading dose of $600 \mathrm{mg}$ was reported to reduce the proportion of low responders, though not all patients would benefit from such an increased dose. ${ }^{12,64}$

\section{Novel Oral P2Y12 Inhibitors: Prasugrel and Ticagrelor}

Prasugrel. In 1993, Japanese researchers claimed the patent for a series of hydrothienopyridine derivatives with antithrombotic activity. ${ }^{78,79}$ Among these, prasugrel was shown to have a greater antithrombotic effect than clopidogrel. Studies in rodents showed that it had additional properties, such as a longer and more intense effect. ${ }^{78}$ In 2009, the FDA approved prasugrel for use in patients with acute coronary syndrome undergoing percutaneous coronary intervention. ${ }^{80}$

Prasugrel is also a prodrug and must be metabolized to be active. After being absorbed, it is rapidly esterase-hydrolyzed to an inactive thiolactone, which, in turn, is oxidized in the liver by CYP, leading to the formation of the active metabolite R138727. ${ }^{47,78}$ Despite being extensive, the metabolism of prasugrel is rapid. The presence of the active metabolite in the plasma approximately 15 minutes after its administration is a consequence of this phenomenon. ${ }^{81}$ Its half-life is around 7.4 hours, the maximum plasma concentration occurs around 30 minutes, and the antiplatelet action lasts for about 96 hours. $^{66,78,81}$ It is possible to obtain clinically meaningful levels of the active metabolite with daily maintenance doses of 5 or $10 \mathrm{mg}$, much lower than those used for clopidogrel ( $75 \mathrm{mg}$ per day). ${ }^{78}$ The activation, which occurs in 1 hepatic step, is different from that of clopidogrel, which requires a second oxidation stage.

Prasugrel is mainly converted by CYP3A4. Because it is converted by a number of isoenzymes of the CYP complex, some studies have observed that when a single isoenzyme involved in the formation of R-138727 is compromised, the others may fulfill the need instead, ensuring the formation of the active metabolite. ${ }^{78}$ In this case, it is possible that prasugrel is less subject to hyporesponsiveness phenomena than clopidogrel. ${ }^{47}$ The use of prasugrel is contraindicated in patients with severe hepatic impairment due to their metabolism by CYP, and the dose adjustment may be used in the case of mild liver disease, though there is no clear evidence on the subject.

Proton pump inhibitors, such as omeprazole and pantoprazole, are known to reduce the effect of clopidogrel due to interference with CYP2C19. ${ }^{67}$ Interaction of these drugs with prasugrel was not observed. ${ }^{78}$ It is believed that prasugrel does not require dosage adjustment when administered concomitantly with drugs that are metabolized by the CYP. ${ }^{47}$ The use of the antiretroviral ritonavir has, however, been reported to inhibit the formation of the active metabolite. ${ }^{67}$ Additionally, concomitant administration of ketoconazole (a potent CYP3A5 inhibitor) decreased the maximum active metabolite concentration of prasugrel by $46 \%$, despite its antiplatelet effect being preserved. ${ }^{66,67}$

Patients with diabetes mellitus have been reported to respond favorably to prasugrel as part of dual-antiplatelet therapy. ${ }^{78,82}$ The greater efficacy of prasugrel (a 60-mg loading dose and a 10-mg daily maintenance dose) over clopidogrel (a 300-mg loading dose and a 75-mg daily maintenance dose) in reducing the combined rate of death from cardiovascular disease, nonfatal acute myocardial infarction, and stroke after percutaneous coronary intervention in patients with acute coronary syndrome was observed in the Trial to Assess Improvement in Therapeutic Outcomes by Optimizing Platelet Inhibition with Prasugrel-Thrombolysis in Myocardial Infarction (TRITON-TIMI 38) study, ${ }^{83,84}$ but prasugrel led to an increase in the rate of bleeding. In the secondary prevention of recurrent stroke, a lower dose $(3.75 \mathrm{mg})$ was assessed in a clinical trial with 3747 Japanese patients, the comparison of PRAsugrel and clopidogrel in Japanese patients with ischemic STROke (the PRASTRO-I trial). ${ }^{85}$ The study failed to demonstrate that this lower dose of prasugrel was noninferior to $75 \mathrm{mg}$ of clopidogrel because the relative-risk confidence interval exceeded predefined margins. In the trial, the proportion of patients who experienced bleeding was similar. This was also the case in the subsequent study (PRASTRO-II), which compared 2.5 and $2.75 \mathrm{mg}$ of prasugrel with $50 \mathrm{mg}$ of clopidogrel. ${ }^{86}$

Prasugrel is similar in its structure and mechanism of action to clopidogrel, but its greater potency and the faster onset may be advantageous when a fast preoperative preparation or rescue 
antiaggregation is needed. ${ }^{47}$ Conversely, these characteristics increase the severity of bleeding if it occurs. In addition, considerable discussion exists on whether they increase the risk of intracranial hemorrhage per se.

A comparative study with 76 patients in neurology procedures ( $n=86)$ found a higher risk of bleeding with dual-antiplatelet therapy when using a full dose of prasugrel (60-mg loading dose and $10-\mathrm{mg}$ /day maintenance) than when using clopidogrel. ${ }^{24}$ Hemorrhagic complications were observed in a total of $3.6 \%$ patients treated with clopidogrel and aspirin and $19.4 \%$ of those treated with prasugrel and aspirin. This observation suggests that the antiplatelet regimen could be related to an increase in the rate of bleeding. Various degrees of vascular injury may occur during endovascular procedures, ranging from clinically insignificant arterial wall damage to clear perforations with active extravasation. The platelet inhibition obtained with prasugrel and aspirin may facilitate occult bleeding progressing to a major, clinically significant hemorrhagic event. ${ }^{24}$ For many authors, clopidogrel remains the drug of choice. In cases of resistance, other antiplatelet agents may be necessary. Patients under prasugrel in interventional neuroradiology series were mostly those who presented with resistance to clopidogrel. ${ }^{24,78}$ Moreover, sample sizes in interventional neuroradiology have been relatively smaller.

With a 60 -mg loading dose of prasugrel, approximately 50\% platelet inhibition is observed at 30 minutes and approaches the maximum effect before 2 hours. ${ }^{78}$ A daily dose of $10 \mathrm{mg}$ also results in a greater platelet inhibition than that achieved with the usual $75 \mathrm{mg}$ of clopidogrel. ${ }^{47,78}$ Patients taking clopidogrel who switch to prasugrel do not lose the antiplatelet effects in the transition. Because prasugrel is an irreversible inhibitor, it takes 710 days for the patient to experience normal platelet function. ${ }^{13,47}$ The high risk of hemorrhage and the increasing use of prasugrel in an at-risk population made it necessary for the FDA to issue a warning. ${ }^{87}$ It was recommended to prefer a reduced maintenance dose $(5 \mathrm{mg}$ /day) in patients weighing $<60 \mathrm{~kg}$ and to reserve this drug for patients younger than 75 years of age in the presence of a risk factor for thrombosis.

In 2013, a chart review of 16 cases of patients allergic or hyporesponsive to clopidogrel who received prasugrel and underwent neurointerventional procedures reported favorable results with no cerebral ischemia or evident intracranial hemorrhage. ${ }^{36}$ In a French study with 2 parallel groups of 100 patients, the use of prasugrel in patients undergoing endovascular treatment of nonruptured cerebral aneurysms was not related to hemorrhagic events. ${ }^{37}$ Prasugrel also potentially reduced, in comparison with clopidogrel, the clinical consequences of thromboembolic complications. In a retrospective study on 297 cases, a notable reduction in the frequency of procedure-related thromboembolism in subjects with unruptured cerebral aneurysms was observed. ${ }^{27}$ The VerifyNow system showed lower values of P2Y12 reactive units and higher inhibition percentages in the prasugrel group, but the rate of hemorrhagic complications did not increase.

In a recent study, Higashiguchi et $\mathrm{al}^{31}{ }^{31}$ in 2021, proposed a tailored therapy in which prasugrel replaced clopidogrel when the result of the VerifyNow assay was inferior to 240 P2Y12 reactive units. They observed a reduction in the frequency of thromboembolic complications after treatment of unruptured aneurysms (16\% versus $6 \%, P<.048, n=217$ ) after a 1-month follow-up without an increase in the rate of hemorrhagic complications. It is, therefore, clear that specific prospective studies on patients in neurovascular procedures and larger samples are now necessary. ${ }^{36}$

Ticagrelor. Ticagrelor is rapidly absorbed, has a half-life of 712 hours, and reaches its maximum concentration approximately 2-3 hours after administration. ${ }^{48}$ A classic loading dose is $180 \mathrm{mg}$, and the maintenance dose is $90 \mathrm{mg} .{ }^{88}$ The drug has a reversible effect on P2Y12 receptors, making it a temporary allosteric antagonist. Thus, its effect can be assessed by VerifyNow. ${ }^{89}$ Because ticagrelor does not require hepatic activation, it may be advantageous in patients with a genetic mutation in the enzyme CYP2C19 or when the situation calls for urgent antiaggregation. ${ }^{48}$ The prevalence of hyporesponsiveness appears to be extremely low. ${ }^{39}$

Ticagrelor is known to be a substrate and a weak inhibitor of CYP3A. It is extensively metabolized by CYP3A4 and, to a lesser, extent by CYP3A5. ${ }^{90}$ As a consequence, strong CYP3A4 inhibitors, such as ketoconazole, increase ticagrelor exposure, and combined use is not recommended. ${ }^{67,91}$ Moderate inhibitors, however, such as diltiazem are not contraindicated. Additionally, potent inducers of CYP3A4 may reduce the efficacy of the drug. For example, rifampicin may decrease its maximum concentration. Coadministration of ticagrelor with CYP3A4 substrates with a narrow therapeutic index is also not recommended because it can increase the exposure of these drugs. Statins are metabolized by CYP3A4. Within an interaction study in healthy volunteers, an increase in the maximal concentration of simvastatin was observed when coadministered with ticagrelor. ${ }^{92}$ Coadministration of ticagrelor with doses of simvastatin or lovastatin of $>40 \mathrm{mg} /$ day could result in adverse effects caused by the statins, such as gastrointestinal disorders and headache. ${ }^{91}$

Ticagrelor leads to platelet inhibition faster and more intensively than clopidogrel. ${ }^{93}$ Its effects also fade more quickly. Ticagrelor coadministered with aspirin has been shown to lead to adequate $\mathrm{P} 2 \mathrm{Y} 12$ inhibition in patients resistant to clopidogrel. ${ }^{93} \mathrm{~A}$ randomized, double-blind trial comparing ticagrelor with clopidogrel in patients with coronary artery disease found that ticagrelor was associated with higher rates of inhibition, including in low responders to clopidogrel. ${ }^{90}$ A multicentric trial of 18,624 patients with acute coronary syndrome showed that ticagrelor was characterized as a fast and potent antiplatelet agent, with an overall favorable safety profile in patients in cardiology studies. ${ }^{48,94,95}$ Compared with classic treatment regimens, the drug appears to be more effective in preventing ischemic coronary events but comes with an increase in the rate of non-procedure-related bleeding. ${ }^{48,95}$

In an interventional neuroradiology series in 2014, eighteen subjects who did not respond to clopidogrel were treated with ticagrelor. ${ }^{39}$ The result was favorable, in the sense that ticagrelor could effectively replace clopidogrel, but 1 event is worth noting: A patient nonresponsive to clopidogrel was forced to switch from ticagrelor to clopidogrel after a flow-diverter placement due to a shortage of the drug. This patient developed partial thrombosis after his treatment was changed. This incident further suggests the efficacy of ticagrelor but calls attention to the potentially serious consequences of stopping treatment with the drug. In this context, ticagrelor may be considered an alternative antiplatelet agent, but its indication should be evaluated on a case-by-case 
basis. Chronic use of ticagrelor is associated with greater drawbacks than clopidogrel.

Elderly patients have a higher drug exposure compared with younger ones, and women have greater exposure than men. ${ }^{91}$ Most interesting, elderly patients also have a lower platelet aggregation index, suggesting that platelets are less sensitive in this subgroup. Despite these differences, no age- or sex-related dose adjustment has been recommended. Renal insufficiency does not seem to influence dosing needs to a significant degree. ${ }^{91}$ However, exposure is increased in patients with mild hepatic impairment. Because changes in pharmacodynamics or tolerability are not significant, dose adjustment in these groups does not seem necessary, but caution must be used because there are still no available data on patients with moderate or severe hepatic impairment. ${ }^{48}$

Bleeding is the main safety concern. An increased risk of minor bleeding with ticagrelor compared with clopidogrel was reported, though there were few major bleeding events. ${ }^{91}$ Although the percentages were small, an increase in fatal intracranial bleeding with ticagrelor compared with clopidogrel $(0.1 \%$ versus $0.01 \%)$ was noted in the PLATelet inhibition and patient Outcomes (PLATO) trial in patients in a cardiology study. ${ }^{95}$ Bleeding times also increase in patients on ticagrelor compared with those on clopidogrel. ${ }^{91}$ Dyspnea is another frequent adverse event, but the need to discontinue therapy because of it does not seem to be very common. ${ }^{48,91}$

Narata et $\mathrm{al}^{46}$ in 2019, analyzed a consecutive series of 154 patients with unruptured aneurysms undergoing stent placement or flow-diverter implantation procedures under aspirin and ticagrelor. The authors observed more neurologic complications than in previous neurointerventional reports that used aspirin with ticagrelor or clopidogrel, but all observed deaths $(n=4)$ were related to intracranial hemorrhaging. They reported that the number of neurologic complications was lower when a lower dose of heparin was used and indicated that more neurovascular studies comparing clopidogrel with ticagrelor under different heparin regimens are necessary. ${ }^{46}$ In the same year, Soize et al ${ }^{45}$ reported a study of 80 patients undergoing aneurysm treatment with a flow diverter/disrupter in which dual-antiplatelet therapy with aspirin and clopidogrel was compared with aspirin and ticagrelor. After 1 month, no significant difference was observed between groups regarding thromboembolic complications or hemorrhage. After 3 months, no delayed infarction or hemorrhage was observed.

In a 2020 study of 72 patients comparing rates of thromboembolism after stent-assisted coiling for unruptured aneurysms, postprocedural infarction was observed on diffusion-weighted imaging more frequently in the ticagrelor group than in the aspirin-plusclopidogrel group. ${ }^{41}$ After multivariable logistic regression analysis, however, the authors concluded that postprocedural infarction was more associated with aneurysm type than antiplatelet medication per se in their series.

In the Acute Stroke or Transient Ischaemic Attack Treated with Aspirin or Ticagrelor and Patient Outcomes (SOCRATES) trial, which compared ticagrelor with aspirin in 13,199 patients with acute stroke or transient ischemic attack, ticagrelor was not found to be superior to aspirin in reducing the rate of stroke, myocardial infarction, or death at 90 days, and no increase in intracranial bleeding was observed. ${ }^{96}$ Nevertheless, increased rates of minor bleeding and dyspnea were noted. The rates of discontinuation of treatment due to dyspnea or any bleeding were $6.2 \%$ and $1.3 \%$, respectively, in the ticagrelor group and $1.4 \%$ and $0.3 \%$, respectively, in the aspirin group. More recently, the Acute Stroke or Transient Ischaemic Attack Treated with Ticagrelor and Aspirin for Prevention of Stroke and Death (THALES) trial compared ticagrelor and aspirin to aspirin alone for the same conditions in a total of 11,016 patients. ${ }^{97}$ The risk of a stroke or death within 30 days was lower with dual therapy, but there was no difference in the incidence of disability. Severe bleeding was more frequent with ticagrelor $(n=28,0.5 \%$ of severe bleeding, $0.4 \%$ intracranial bleeding). These rates of bleeding in the intracranial space were within the range observed with patients taking clopidogrel and aspirin in the Clopidogrel in High-Risk Patients with Acute Nondisabling Cerebrovascular Events (CHANCE) trial $(0.3 \%$ with moderate and severe hemorrhage, $0.3 \%$ with hemorrhagic stroke) and the Platelet-Oriented Inhibition in New TIA and Minor Ischemic Stroke (POINT) trial (0.9\% with major hemorrhage, $0.2 \%$ with intracranial bleeding). ${ }^{8,9}$

An important topic of discussion is the reversibility of the effect of ticagrelor. It was reported that although the antiaggregation induced by aspirin could be efficiently reversed by platelet transfusion, the same cannot be accomplished with ticagrelor. Even in high doses, platelets do not seem to be a potent antidote. Because the drug reversibly binds the P2Y12 receptor, the suggested mechanism is that circulating ticagrelor and its active metabolite inhibit the fresh platelets administered. ${ }^{98}$ In an in vitro and ex vivo study, gel-filtered platelets from patients who had received ticagrelor were shown to suppress donor platelet function after mixing, suggesting the transfer of ticagrelor to the donor platelets without recovery of the responsiveness of the patient's platelets. ${ }^{99}$ Antibody-based strategies are emerging as a potential pathway for achieving rapid drug reversal. ${ }^{100}$

\section{CONCLUSIONS}

In the domain of interventional neuroradiology, antiplatelet treatment is intended to reduce the risk of perioperative thromboembolic phenomena. For preoperative preparation, clopidogrel is used very frequently and point-of-care aggregometry tests have been developed. Nevertheless, in a considerable number of patients, significant resistance to the drug is observed in association with a risk for cerebral ischemia after implantation of intracranial endovascular material. Prasugrel and ticagrelor are proving to be promising drugs, given their effective use in patients with resistance to clopidogrel. There remains, however, a need for larger studies on patients in neurointerventional procedures, in particular regarding treatment tailoring. The same is true of reversal strategies, particularly for ticagrelor.

\section{REFERENCES}

1. Gorelick PB, Farooq MU. Advances in our understanding of "resistance" to antiplatelet agents for prevention of ischemic stroke. Stroke Res Treat 2013;2013:727842 CrossRef Medline

2. Lee DH, Arat A, Morsi H, et al. Dual antiplatelet therapy monitoring for neurointerventional procedures using a point-of-care platelet function test: a single-center experience. AJNR Am J Neuroradiol 2008;29:1389-94 CrossRef Medline 
3. Muller-Schunk S, Linn J, Peters N, et al. Monitoring of clopidogrelrelated platelet inhibition: correlation of nonresponse with clinical outcome in supra-aortic stenting. AJNR Am J Neuroradiol 2008;29:786-91 CrossRef Medline

4. Pandya DJ, Fitzsimmons BF, Wolfe TJ, et al. Measurement of antiplatelet inhibition during neurointerventional procedures: the effect of antithrombotic duration and loading dose. J Neuroimaging 2010;20:64-69 CrossRef Medline

5. Prabhakaran S, Wells KR, Lee VH, et al. Prevalence and risk factors for aspirin and clopidogrel resistance in cerebrovascular stenting. AJNR Am J Neuroradiol 2008;29:281-85 CrossRef Medline

6. Wagner H, Angiolillo DJ, ten Berg JM, et al. Higher body weight patients on clopidogrel maintenance therapy have lower active metabolite concentrations, lower levels of platelet inhibition, and higher rates of poor responders than low body weight patients. $J$ Thromb Thrombolysis 2014;38:127-33 CrossRef Medline

7. Falcao FJ, Carvalho L, Chan M, et al. P2Y12 platelet receptors: importance in percutaneous coronary intervention. Arq Bras Cardiol 2013;101:277-82 CrossRef Medline

8. Wang $\mathrm{Y}$, Wang $\mathrm{Y}$, Zhao $\mathrm{X}$, et al. Clopidogrel with aspirin in acute minor stroke or transient ischemic attack. N Engl J Med 2013;369:1119 CrossRef Medline

9. Johnston SC, Easton JD, Farrant M, et al. Clinical Research Collaboration, Neurological Emergencies Treatment Trials Network, and the POINT Investigators. Clopidogrel and aspirin in acute ischemic stroke and high-risk TIA. N Engl J Med 2018;379:215-25 CrossRef Medline

10. Hussein HM, Emiru T, Georgiadis AL, et al. Assessment of platelet inhibition by point-of-care testing in neuroendovascular procedures. AJNR Am J Neuroradiol 2013;34:700-06 CrossRef Medline

11. Maldonado IL, Seris C, Mernes R, et al. Clopidogrel-related platelet inhibition: correlation with perioperative adverse events in neurointerventional procedures. The eJournal of the European Society of Minimally Invasive Neurological Therapy. 2014. http://ejmint.org/sites/ default/files/pdf/original_article_1437000160.pdf. Accessed March 14, 2021

12. Tan LA, Keigher KM, Munich SA, et al. Thromboembolic complications with Pipeline Embolization Device placement: impact of procedure time, number of stents and pre-procedure P2Y12 reaction unit (PRU) value. J NeuroIntervent Surg 2015;7:217-21 CrossRef Medline

13. Gandhi CD, Bulsara KR, Fifi J, et al; SNIS Standards and Guidelines Committee. Platelet function inhibitors and platelet function testing in neurointerventional procedures. J Neurointerv Surg 2014;6:567-77 CrossRef Medline

14. Nordeen JD, Patel AV, Darracott RM, et al. Clopidogrel resistance by $\mathrm{P} 2 \mathrm{Y} 12$ platelet function testing in patients undergoing neuroendovascular procedures: incidence of ischemic and hemorrhagic complications. J Vasc Interv Neurol 2013;6:26-34 Medline

15. Drazin D, Choulakian A, Nuno M, et al. Body weight: a risk factor for subtherapeutic antithrombotic therapy in neurovascular stenting. J Neurointerv Surg 2011;3:177-81 CrossRef Medline

16. Fifi JT, Brockington C, Narang J, et al. Clopidogrel resistance is associated with thromboembolic complications in patients undergoing neurovascular stenting. AJNR Am J Neuroradiol 2013;34:716-20 CrossRef Medline

17. Flechtenmacher N, Kämmerer F, Dittmer R, et al. Clopidogrel resistance in neurovascular stenting: correlations between light transmission aggregometry, VerifyNow, and the Multiplate. AJNR Am J Neuroradiol 2015;36:1953-58 CrossRef Medline

18. de Souza R, Pena MI, de Vasconcelos AV, et al. Carotid and vertebral artery stenting: REMAT data (Madre Teresa Registry). Revista Brasileira de Cardiologia Invasiva 2013;21:152-58 CrossRef

19. Asai T, Miyachi S, Izumi T, et al. Relationship between low response to clopidogrel and periprocedural ischemic events with coil embolization for intracranial aneurysms. J Neurointerv Surg 2016;8:752-55 CrossRef Medline
20. Daou B, Starke RM, Chalouhi N, et al. P2Y12 reaction units: effect on hemorrhagic and thromboembolic complications in patients with cerebral aneurysms treated with the Pipeline Embolization Device. Neurosurgery 2016;78:27-33 CrossRef Medline

21. Nishi H, Nakahara I, Matsumoto S, et al. Platelet reactivity and hemorrhage risk in neurointerventional procedures under dual antiplatelet therapy. J Neurointerv Surg 2016;8:949-53 CrossRef Medline

22. Holmes DR Jr, Dehmer GJ, Kaul S, et al. Society for Cardiovascular Angiography Interventions, Society of Thoracic Surgeons, Writing Committee Members, ACCF/AHA Clopidogrel clinical alert: approaches to the FDA "boxed warning": a report of the American College of Cardiology Foundation Task Force on Clinical Expert Consensus Documents and the American Heart Association. Circulation 2010;122:537-57 CrossRef Medline

23. United States Food \& Drug Administration. FDA Drug Safety Communication: Reduced effectiveness of Plavix (clopidogrel) in patients who are poor metabolizers of the drug. https://www.fda. gov/drugs/postmarket-drug-safety-information-patients-andproviders/fda-drug-safety-communication-reduced-effectivenessplavix-clopidogrel-patients-who-are-poor. Accessed July 8, 2021

24. Akbari SH, Reynolds MR, Kadkhodayan Y, et al. Hemorrhagic complications after prasugrel (Effient) therapy for vascular neurointerventional procedures. J Neurointerv Surg 2013;5:337-43 CrossRef Medline

25. Atallah E, Saad H, Bekelis K, et al. The use of alternatives to clopidogrel in flow-diversion treatment with the Pipeline Embolization Device. J Neurosurg 2018;129:1130-35 CrossRef Medline

26. Choi HH, Cho YD, Han MH, et al. Antiplatelet premedicationfree stent-assisted coil embolization in acutely ruptured aneurysms. World Neurosurg 2018;114:e1152-60 CrossRef Medline

27. Choi HH, Lee JJ, Cho YD, et al. Antiplatelet premedication for stentassisted coil embolization of intracranial aneurysms: low-dose prasugrel vs clopidogrel. Neurosurgery 2018;83:981-88 CrossRef Medline

28. Delgado Almandoz JE, Crandall BM, Scholz JM, et al. Pre-procedure P2Y12 reaction units value predicts perioperative thromboembolic and hemorrhagic complications in patients with cerebral aneurysms treated with the Pipeline Embolization Device. J Neurointerv Surg 2013;5:iii3-10 CrossRef Medline

29. Delgado Almandoz JE, Crandall BM, Scholz JM, et al. Last-recorded P2Y12 reaction units value is strongly associated with thromboembolic and hemorrhagic complications occurring up to 6 months after treatment in patients with cerebral aneurysms treated with the Pipeline Embolization Device. AJNR Am J Neuroradiol 2014;35:128-35 CrossRef Medline

30. Ha EJ, Cho WS, Kim JE, et al. Prophylactic antiplatelet medication in endovascular treatment of intracranial aneurysms: low-dose prasugrel versus clopidogrel. AJNR Am J Neuroradiol 2016;37:206065 CrossRef Medline

31. Higashiguchi S, Sadato A, Nakahara I, et al. Reduction of thromboembolic complications during the endovascular treatment of unruptured aneurysms by employing a tailored dual antiplatelet regimen using aspirin and prasugrel. J Neurointerv Surg 2021 Feb 25. [Epub ahead of print] CrossRef Medline

32. Kurniawan RG, Song Y, Kwon B, et al. Tailored antiplatelet agent medication in clopidogrel hyporesponsive patients before stent-assisted coiling: single-center experience. Neuroradiology 2020;62:1709-15 CrossRef Medline

33. Lee D, Song Y, Han M, et al. Low-dose prasugrel in patients with resistance to clopidogrel for the treatment of cerebral aneurysms. Neurointervention 2018;13:124-27 CrossRef Medline

34. Oran I, Cinar C, Gok M, et al. Aggregometry response to half-dose prasugrel in flow-diverting stent implantation. Clin Neuroradiol 2020;30:463-69 CrossRef Medline

35. Parthasarathy R, Gupta V, Gupta A. Safety of prasugrel loading in ruptured blister like aneurysm treated with a Pipeline Device. $\mathrm{Br} J$ Radiol 2018;91:20170476 CrossRef Medline 
36. Stetler WR, Chaudhary N, Thompson BG, et al. Prasugrel is effective and safe for neurointerventional procedures. J Neurointerv Surg 2013;5:332-36 CrossRef Medline

37. Sedat J, Chau Y, Gaudart J, et al. Prasugrel versus clopidogrel in stent-assisted coil embolization of unruptured intracranial aneurysms. Interv Neuroradiol 2017;23:52-59 CrossRef Medline

38. DeGrote JR, Olafson EM, Drofa A, et al. Ticagrelor and acetylsalicylic acid after placement of Pipeline Embolization Device for cerebral aneurysm: a case series. Can J Hosp Pharm 2019;71:349-55

39. Hanel RA, Taussky P, Dixon T, et al. Safety and efficacy of ticagrelor for neuroendovascular procedures: a single-center initial experience. J Neuronterv Surg 2014;6:320-22 CrossRef

40. Kang HS, Kwon BJ, Kim JE, et al. Preinterventional clopidogrel response variability for coil embolization of intracranial aneurysms: clinical implications. AJNR Am J Neuroradiol 2010;31:120610 CrossRef Medline

41. Kim SH, Lee H, Kim SB, et al. Differences in thromboembolism after stent-assisted coiling for unruptured aneurysms between aspirin plus clopidogrel and ticagrelor. J Clin Neurosci 2020;82:128-33 CrossRef Medline

42. Mohammaden MH, English SW, Stapleton CJ, et al. Safety and efficacy of ticagrelor as single antiplatelet therapy in prevention of thromboembolic complications associated with the Pipeline Embolization Device (PED): multicenter experience. J Neurointerv Surg 2020;12:1113-16 CrossRef Medline

43. Moore JM, Adeeb N, Shallwani H, et al. A multicenter cohort comparison study of the safety, efficacy, and cost of ticagrelor compared to clopidogrel in aneurysm flow diverter procedures. Neurosurgery 2017;81:665-71 CrossRef Medline

44. Park KY, Ozaki T, Kostynskyy A, et al. Ticagrelor versus clopidogrel in the dual antiplatelet regimen for intracranial stenting or flow-diverter treatment for unruptured cerebral aneurysms: a single-center cohort study. AJNR Am J Neuroradiol 2021;42:163844 CrossRef Medline

45. Soize S, Foussier C, Manceau PF, et al. Comparison of two preventive dual antiplatelet regimens for unruptured intracranial aneurysm embolization with flow diverter/disrupter: a matchedcohort study comparing clopidogrel with ticagrelor. J Neuroradiol 2019;46:378-83 CrossRef Medline

46. Narata AP, Amelot A, Bibi R, et al. Dual antiplatelet therapy combining aspirin and ticagrelor for intracranial stenting procedures: a retrospective single center study of 154 consecutive patients with unruptured aneurysms. Neurosurgery 2019;84:77-83 CrossRef Medline

47. Scott DM, Norwood RM, Parra D. P2Y12 inhibitors in cardiovascular disease: focus on prasugrel. Ann Pharmacother 2009;43:6476 CrossRef Medline

48. Capodanno D, Dharmashankar K, Angiolillo DJ. Mechanism of action and clinical development of ticagrelor, a novel platelet ADP P2Y12 receptor antagonist. Expert Rev Cardiovasc Ther 2010;8:151-18 CrossRef Medline

49. Maldonado IL, Machi P, Costalat V, et al. Neuroform stent-assisted coiling of unruptured intracranial aneurysms: short- and midterm results from a single-center experience with 68 patients. AJNR Am J Neuroradiol 2011;32:131-36 CrossRef Medline

50. Gurbel PA, Bliden KP, Hiatt BL, et al. Clopidogrel for coronary stenting: response variability, drug resistance, and the effect of pretreatment platelet reactivity. Circulation 2003;107:2908-13 CrossRef Medline

51. Koerner H, Derveaux C, Alexandrou M, et al. Do clopidogrel nonresponders have an increased risk of adverse events during supraaortal angioplasty and stenting? Stroke Res Treat 2012;2012:904534 CrossRef Medline

52. Angiolillo DJ, Fernandez-Ortiz A, Bernardo E, et al. Identification of low responders to a 300-mg clopidogrel loading dose in patients undergoing coronary stenting. Thromb Res 2005;115:10108 CrossRef Medline
53. Karan V, Vyas D, Bohra V, et al. Ticagrelor use in Indian patients undergoing neuroendovascular procedures: a single center experience. Neurointervention 2019;14:125-30 CrossRef Medline

54. Yi HJ, Hwang G, Lee BH. Variability of platelet reactivity on antiplatelet therapy in neurointervention procedure. $J$ Korean Neurosurg Soc 2019;62:3-9 CrossRef Medline

55. Goh C, Churilov L, Mitchell P, et al. Clopidogrel hyper-response and bleeding risk in neurointerventional procedures. AJNR Am J Neuroradiol 2013;34:721-26 CrossRef Medline

56. Nakagawa I, Park HS, Yokoyama S, et al. Influence of diabetes mellitus and cigarette smoking on variability of the clopidogrel-induced antiplatelet effect and efficacy of active management of the target $\mathrm{P} 2 \mathrm{Y} 12$ reaction unit range in patients undergoing neurointerventional procedures. J J Stroke Cerebrovasc Dis.2016;25:163-71 CrossRef Medline

57. Anderson CD, Biffi A, Greenberg SM, et al. Personalized approaches to clopidogrel therapy: are we there yet? Stroke 2010;41:2997-3002 CrossRef Medline

58. Wallentin L. P2Y(12) inhibitors: differences in properties and mechanisms of action and potential consequences for clinical use. Eur Heart J 2009;30:1964-77 CrossRef Medline

59. Sunderland N, Skroblin P, Barwari T, et al. MicroRNA biomarkers and platelet reactivity: the clot thickens. Circ Res 2017;120:418-35 CrossRef Medline

60. Zhang YJ, Li MP, Tang J, et al. Pharmacokinetic and pharmacodynamic responses to clopidogrel: evidences and perspectives. Int $J$ Environ Res Public Health 2017;14:301 CrossRef Medline

61. Willeit P, Zampetaki A, Dudek K, et al. Circulating microRNAs as novel biomarkers for platelet activation. Circ Res 2013;112:595600 CrossRef Medline

62. Luchessi AD, Silbiger VN, Cerda A, et al. Increased clopidogrel response is associated with $\mathrm{ABCC} 3$ expression: a pilot study. Clin Chim Acta 2012;413:417- 21 CrossRef Medline

63. Su J, Li X, Yu Q, et al. Association of P2Y12 gene promoter DNA methylation with the risk of clopidogrel resistance in coronary artery disease patients. Biomed Res Int 2014;2014:1-8 CrossRef Medline

64. Neubauer H, Kaiser AF, Endres HG, et al. Tailored antiplatelet therapy can overcome clopidogrel and aspirin resistance: the BOchum CLopidogrel and Aspirin Plan (BOCLA-Plan) to improve antiplatelet therapy. BMC Med 2011;9:3 CrossRef Medline

65. Gasparyan AY. Aspirin and clopidogrel resistance: methodological challenges and opportunities. Vasc Health Risk Manag 2010;6:10912 CrossRef Medline

66. Farid NA, Payne CD, Small DS, et al. Cytochrome P450 3A inhibition by ketoconazole affects prasugrel and clopidogrel pharmacokinetics and pharmacodynamics differently. Clin Pharmacol Ther 2007;81:735-41 CrossRef Medline

67. Siller-Matula JM, Trenk D, Krähenbühl S, et al. Clinical implications of drug-drug interactions with $\mathrm{P} 2 \mathrm{Y} 12$ receptor inhibitors. $J$ Thromb Haemost 2014;12:2-13 CrossRef Medline

68. Gabriel SA, Beteli CB, Tanighuchi RS, et al. Aspirin resistance and atherothrombosis. Rev Bras Cir Cardiovasc 2007;22:96-103 CrossRef Medline

69. Judge HM, Patil SB, Buckland RJ, et al. Potentiation of clopidogrel active metabolite formation by rifampicin leads to greater P2Y12 receptor blockade and inhibition of platelet aggregation after clopidogrel: P2Y12 receptor blockade. J Thromb Haemost 2010;8:182027 CrossRef Medline

70. Bliden KP, DiChiara J, Lawal L, et al. The association of cigarette smoking with enhanced platelet inhibition by clopidogrel. $\mathrm{J} \mathrm{Am}$ Coll Cardiol 2008;52:531-33 CrossRef Medline

71. Elsherbiny ME, Brocks DR. The ability of polycyclic aromatic hydrocarbons to alter physiological factors underlying drug disposition. Drug Metab Rev 2011;43:457-75 CrossRef Medline

72. Desai NR, Mega JL, Jiang S, et al. Interaction between cigarette smoking and clinical benefit of clopidogrel. J Am Coll Cardiol 2009;53:1273-78 CrossRef Medline 
73. Sibbing $\mathrm{D}$, von Beckerath $\mathrm{O}$, Schömig $\mathrm{A}$, et al. Impact of body mass index on platelet aggregation after administration of a high loading dose of $600 \mathrm{mg}$ of clopidogrel before percutaneous coronary intervention. Am Jo Cardiol 2007;100:203-05 CrossRef Medline

74. Wong P, Tesoro E, Aletich V, et al. Accumetrics-based clopidogrel dosing in endovascular neurosurgery. Neurol Res 2015;37:9981005 CrossRef Medline

75. Ari H, Ozkan H, Karacinar A, et al. The EFFect of hIgh-dose ClopIdogrel treatmENT in patients with clopidogrel resistance (the EFFICIENT trial). Int J Cardiol 2012;157:374-80 CrossRef Medline

76. Collet JP, Hulot JS, Anzaha G, et al. High doses of clopidogrel to overcome genetic resistance: the randomized crossover CLOVIS2 (Clopidogrel and Response Variability Investigation Study 2). JACC Cardiovasc Interv 2011;4:392-402 CrossRef Medline

77. Zhuo X, Zhuo B, Ouyang S, et al. Adverse clinical outcomes associated with double dose clopidogrel compared to the other antiplatelet regimens in patients with coronary artery disease: a systematic review and meta-analysis. BMC Pharmacol Toxicol 2018;19:54 CrossRef Medline

78. Shan J, Sun H. The discovery and development of prasugrel. Expert Opin Drug Discov 2013;8:897-905 CrossRef Medline

79. Koike H, Asai F, Sugidachi A, et al. Hydropyridine derivatives having antithrombotic activity. CA2077695 1993

80. Center for Drug Evaluation and Research. EFFIENT ${ }^{\mathrm{TM}}$ Approval letter. (NDA 22-307). https://www.accessdata.fda.gov/drugsatfda_ docs/appletter/2009/022307s000_ltr.pdf. Accessed July 8, 2021

81. Norgard NB, Dinicolantonio JJ. Clopidogrel, prasugrel, or ticagrelor? A practical guide to use of antiplatelet agents in patients with acute coronary syndromes. Postgrad Med 2013;125:91-102 CrossRef Medline

82. Wiviott SD, Braunwald E, Angiolillo DJ, et al. Greater clinical benefit of more intensive oral antiplatelet therapy with prasugrel in patients with diabetes mellitus in the trial to assess improvement in therapeutic outcomes by optimizing platelet inhibition with prasugrel-Thrombolysis in Myocardial Infarction 38. Circulation 2008;118:1626-36 CrossRef Medline

83. Montalescot G, Wiviott SD, Braunwald E, et al; TRITON-TIMI 38 Investigators. Prasugrel compared with clopidogrel in patients undergoing percutaneous coronary intervention for ST-elevation myocardial infarction (TRITON-TIMI 38): double-blind, randomised controlled trial. Lancet 2009;373:723-31 CrossRef Medline

84. Wiviott SD, Braunwald E, McCabe $\mathrm{CH}$, et al. Prasugrel versus clopidogrel in patients with acute coronary syndromes. $N$ Engl J Med 2007;357:2001-15 CrossRef Medline

85. Ogawa A, Toyoda K, Kitagawa K, et al; PRASTRO-I Study Group. Comparison of prasugrel and clopidogrel in patients with noncardioembolic ischaemic stroke: a phase 3, randomised, non-inferiority trial (PRASTRO-I). Lancet Neurol 2019;18:238-47 CrossRef Medline

86. Kitagawa K, Toyoda K, Kitazono T, et al. Safety and efficacy of prasugrel in elderly/low body weight Japanese patients with ischemic stroke: randomized PRASTRO-II. Cerebrovasc Dis 2020;49:152-59 CrossRef Medline

87. United States Food \& Drug Administration. Highlights of prescribing information. https://www.accessdata.fda.gov/drugsatfda_docs/label/ 2020/022307s018lbl.pdf. Accessed July 8, 2021

88. Byrne JV. Tutorials in Endovascular Neurosurgery and Interventional Neuroradiology. Springer International Publishing; 2017

89. Jeong $\mathrm{YH}$, Bliden $\mathrm{KP}$, Antonino MJ, et al. Usefulness of the VerifyNow P2Y12 assay to evaluate the antiplatelet effects of ticagrelor and clopidogrel therapies. Am Heart J 2012;164:35-42 CrossRef Medline

90. Gurbel PA, Bliden KP, Butler K, et al. Response to ticagrelor in clopidogrel nonresponders and responders and effect of switching therapies: the RESPOND study. Circulation 2010;121:1188-99 CrossRef Medline

91. Dobesh PP, Oestreich JH. Ticagrelor: pharmacokinetics, pharmacodynamics, clinical efficacy, and safety. Pharmacotherapy 2014;34:1077-90 CrossRef Medline

92. Teng R, Mitchell PD, Butler KA. Pharmacokinetic interaction studies of co-administration of ticagrelor and atorvastatin or simvastatin in healthy volunteers. Eur J Clin Pharmacol 2013;69:47787 CrossRef Medline

93. Gurbel PA, Bliden KP, Butler K, et al. Randomized double-blind assessment of the ONSET and OFFSET of the antiplatelet effects of ticagrelor versus clopidogrel in patients with stable coronary artery disease: the ONSET/OFFSET Study. Circulation 2009;120:2577-85 CrossRef Medline

94. James SK, Roe MT, Cannon CP, et al; PLATO Study Group. Ticagrelor versus clopidogrel in patients with acute coronary syndromes intended for non-invasive management: substudy from prospective randomised PLATelet inhibition and patient Outcomes (PLATO) trial. BMJ 2011;342:d3527 CrossRef Medline

95. Wallentin L, Becker RC, Budaj A, et al. Ticagrelor versus clopidogrel in patients with acute coronary syndromes. $N$ Engl $J$ Med 2009;361:1045-57 CrossRef Medline

96. Johnston SC, Amarenco P, Albers GW, et al; SOCRATES Steering Committee and Investigators. Ticagrelor versus aspirin in acute stroke or transient ischemic attack. N Engl J Med 2016;375:35-43 CrossRef Medline

97. Johnston SC, Amarenco P, Denison H, et al; THALES Investigators. Ticagrelor and aspirin or aspirin alone in acute ischemic stroke or TIA. N Engl J Med 2020;383:207-17 CrossRef Medline

98. Godier A, Taylor G, Gaussem P. Inefficacy of platelet transfusion to reverse ticagrelor. $N$ Engl J Med 2015;372:196-97 CrossRef Medline

99. Bertling A, Fender AC, Schungel L, et al. Reversibility of platelet P2Y12 inhibition by platelet supplementation: ex vivo and in vitro comparisons of prasugrel, clopidogrel and ticagrelor. $J$ Thromb Haemost 2018;16:1089-98 CrossRef Medline

100. Bhatt DL, Pollack CV, Weitz JI, et al. Antibody-based ticagrelor reversal agent in healthy volunteers. N Engl J Med 2019;380:1825-33 CrossRef Medline 